\title{
Causes of Subcontracting: \\ Evidence from Panel Data on Construction Firms ${ }^{* *}$
}

\author{
Manuel GONZÁLEZ \\ University of Oviedo \\ Dept. of Business \\ Avda. del Cristo, S/n \\ 33071 Oviedo SPAIN \\ mgdiaz@econo.uniovi.es \\ Benito ARRUÑNADA \\ Pompeu Fabra University \\ Dept. of Economics and Business \\ C/ Ramón Trías Fargas, 25 \\ 08005 Barcelona SPAIN \\ benito.arrunada@econ.upf.es \\ Alberto FERNÁNDEZ \\ Pompeu Fabra University \\ Dept. of Economics and Business \\ C/ Ramón Trías Fargas, 25 \\ 08005 Barcelona SPAIN \\ alberto.fernandez@econ.upf.es
}

\footnotetext{
** Financial support from DGESIC, a research agency of the Spanish Government, through project PB950989 is gratefully acknowledged. Earlier versions of this paper have been presented at several seminars and conferences. We thank all the participants at these meetings and workshops, as well as Antonio Álvarez, Carlos Arias, Marta Fernández, Elena Huergo, Pere Ibern, Scott Masten, Albert Satorra, Frank Stephen and Luis Vázquez for helpful comments. All remaining errors are of course ours.
} 


\title{
Causes of Subcontracting: Evidence from Panel Data on Construction Firms
}

\begin{abstract}
This paper examines factors explaining subcontracting decisions in the construction industry. Rather than the more common cross-sectional analyses, we use panel data to evaluate the influence of all relevant variables. We design and use a new index of the closeness to small numbers situations to estimate the extent of hold-up problems. Results show that as specificity grows, firms tend to subcontract less. The opposite happens when output heterogeneity and the use of intangible assets and capabilities increase. Neither temporary shortage of capacity nor geographical dispersion of activities seem to affect the extent of subcontracting. Finally, proxies for uncertainty do not show any clear effect.
\end{abstract}

JEL codes: L22, L14, L74

Keywords: Intangible assets, monitoring costs, specificity, subcontracting, vertical integration, uncertainty. 


\section{Causes of Subcontracting:}

\section{Evidence from Panel Data on Construction Firms}

\section{Introduction}

We test the vertical integration hypotheses of contractual literature on a representative panel of construction firms from 1987 to $1992 .{ }^{1}$ Our research provides two main improvements over most previous empirical work on make-or-buy decisions from a transaction costs perspective. ${ }^{2}$ First, we calculate asset specificity for each firm using a new index that does not depend on managerial assessments. Second, we use panel data to estimate time and firm-specific effects in subcontracting. Empirical work on transaction costs is largely cross-sectional in nature and, as a result, researchers have been unable to control for unobserved firm-specific effects. ${ }^{3}$ The only exception is franchising, where some empirical work with panel data has been done. ${ }^{4}$

The rest of the paper is organized as follows. Section 2 develops general hypotheses on the subcontracting decision. Section 3 analyzes the main distinctive characteristics of the construction industry and outlines a theory of construction firms. Section 4 describes the data and methodology and goes on to discuss the results. The paper ends with some

1 Besides Coase's (1937) seminal work, classical works about vertical integration are Williamson (1971 and 1975), Klein, Crawford and Alchian (1978), Grossman and Hart (1986), Hart and Moore (1990), Klein (1996), Klein and Murphy (1997) and Poppo and Zenger (1998), among others.

2 Williamson (1985, pp. 103-30), Joskow (1988) and Shelanski and Klein (1995) review the main empirical works about transaction costs.

3 Furthermore, many of the empirical works only use models of qualitative choice. See, for example, Monteverde and Teece (1982), Masten (1984), Anderson and Schmittlein (1984), Walker and Weber (1984 and 1987), Anderson (1985), Masten, Meehan and Snyder (1989), Lieberman (1991) and Masten and Snyder (1993). However, there are more elaborated models (see, for example, Masten, Meehan and Snyder, 1991) and others where the dependent variable is continuous (see, for example, González, Arruñada, and Fernández, 1997, for vertical integration and Lafontaine, 1992 and 1993, for franchising).

4 See Minkler and Park (1994) and Lafontaine and Shaw (1996). 
conclusions and managerial applications.

\section{Factors of the Make-or-Buy Decision}

The key question with respect to vertical integration is ascertaining when the transaction costs of using the market are larger than those of internal organization. Investments in specific assets may create a risk of hold-up, which is one of the most important transactional problems when quasi-rents are high and expropriable. Such problems can be solved or mitigated by means of vertical integration or by the use of contractual safeguards such as formalized long-term contracts and reputation. ${ }^{5}$ Two reasons favor vertical integration. First, transaction costs generated by the hold-up problem are usually higher when the use of assets is negotiated through market transactions than through internal transactions. Second, even for large firms, transaction costs generated by specific assets compensate the specialization advantages of dividing functions between use and ownership. A negative relationship between the intensity of the hold-up problem (specificity) and the extent of subcontracting can then be expected. (Table 2 summarizes the hypotheses).

Williamson (1975, pp. 23-5; and 1985, pp. 43-63) argues that an increase in the difficulty of foreseeing the evolution of transactional variables-i.e. uncertainty-increases the cost of establishing how the participants should act in each possible contingency. This effect is present in both market and organizational transactions although it is frequently considered to be smaller within organizations, ${ }^{6}$ because vertical integration makes it easier to adjust to unforeseen situations. Whereas in most market relationships parties have to agree on detailed plans of action to safeguard themselves from hold-up, contracts are more "relational" in a hierarchy. This means that ex ante agreements only allocate residual

5 The study of asset specificity starts with the pioneer works of Williamson (1975 and 1979) and Klein, Crawford and Alchian (1978). See Klein (1996) for a recent and detailed analysis of specificity.

6 Williamson (1975, p. 25; and 1985, pp. 79-80), Anderson and Schmittlein (1984, pp. 387-8), Masten (1984, p. 405-6), Masten et al. (1991, pp. 7-8), Stuckey and White (1993, p.74) and Ricketts (1994, pp. 185-91). 
decision rights, so that ex post decisions are more flexible. ${ }^{7}$ This flexibility facilitates selfenforcement because it reduces the risk of transactors taking advantage of the necessarily imperfect terms of explicit and detailed agreements, especially in market disturbances. ${ }^{8}$

Nevertheless, this argument must be qualified. Uncertainty may actually decrease vertical integration. First, unlike subcontracting, vertical integration is likely to facilitate opportunistic behavior in market disturbances-uncertain environments. Not only do organizations provide less powerful incentives than markets, it is also more costly to verify opportunistic behavior in an uncertain environment because it is difficult to distinguish whether non-performance arises from self-interested behavior or from a change in the environment. $^{9}$ Second, profit variability derived from uncertainty is detrimental to managers because their compensation is usually tied to firm performance and they frequently have a substantial amount of specific human capital. They therefore tend to integrate activities which correlate negatively with the firm's profits (Perry, 1982). Finally, uncertainty is only relevant for vertical integration decisions if a certain degree of specificity exists: ${ }^{10}$ if a transaction does not require specific investments, contracting costs are small and a new agreement could easily be reached in any new situation.

Uncertainty, therefore, has an ambiguous effect on vertical integration decisions, depending on several factors: the importance of high-powered incentives to avoid opportunism, the correlation between the variability of subcontracted activities and the firm's main activity, and the interaction with specificity. Thus, we expect the direct relationship between uncertainty and subcontracting to be insignificant. If there is any relationship at all, it will be found in the interaction of uncertainty with specificity and will be negative.

\footnotetext{
7 See, for example, Macneil (1978), Goldberg (1980), and Williamson (1985).

8 See Barzel (1989) and Klein and Murphy (1997).

9 Williamson (1985, p. 76).
} 
Another factor influencing the level of conflict among the transactors is the interrelation of each transaction with other exchanges, depending on the actual type of transaction or the geographical location (Coase, 1937, reprint in 1988, pp. 45-6). Integrating an additional transaction usually means an increase in internal monitoring costs which will be determined by the contractual opportunism arising from the type of knowledge required for the new transaction or from its location. On the one hand, the more heterogeneous the required knowledge is in relation to the transactions already integrated, the more expensive internal control will be and the lower the probability of vertical integration. On the other hand, the greater the geographical dispersion of the transactions, the greater the cost of internal control and the less likely the integration of the new transaction. Hence, the more dissimilar the knowledge necessary to carry out the company activities is and/or the more geographically disperse operations are, the greater the probability of subcontracting. We expect, then, to find a positive relationship between both variables—output dissimilarity and geographical dispersion—and subcontracting.

In addition, the actual nature of the information or knowledge required to make a transaction-and not only the difference with respect to other transactions as in the previous case-affects subcontracting decisions. If the required information is embodied in intangible assets, subcontracting will probably decrease since it is costly to use the market for such assets ${ }^{11}$ because it is difficult to verify how they are used. Firms are therefore compelled to integrate activities that are based on them or to leave intangible resources idle because selling the excess capacity in the market causes prohibitive transaction costs. We would therefore expect that the more intangible the resources are, the lower the degree of subcontracting.

10 Williamson (1985, pp. 59-60) and Shelanski and Klein (1995, p. 339).

11 Starting from the pioneer idea of Penrose (1959) that the firm is not only a set of physical resources but also a pool of intangible resources, the Resources and Capabilities Theory provides a strategic view of this problem. See Grant (1991) and Foss (1997) and the references quoted therein. 
Finally, and regardless of conflicts among transactors, there are short-term problems affecting subcontracting decisions, such as temporary lack of productive capacity. Although this is not a long-term cause of subcontracting, many firms resolve any temporary shortages by contracting out to local firms. Considering that firms are more likely to face these problems in a period of economic growth than in declining years, we should find that the greater the industry's growth the higher the degree of subcontracting. However, in the long-run, capacity problems are not a cause of subcontracting since firms tend to adapt their resources to their needs. ${ }^{12}$

\section{The construction firm}

\subsection{Technological Features}

Certain particular characteristics of the construction industry make it substantially different from manufacturing, principally the fact that its final product shows uniqueness, immobility and high variety. ${ }^{13}$ (1) Construction output is the result of a project production system in which the product is adapted to particular buyers, locations, and uses. This uniqueness of the output discourages the use of project-specialized assets, unlike manufacturing industries producing mass products. (2) Construction consists of building immobile structures in a certain location and most of the transformations needed take place on site. Productive assets are therefore moved to the product and not the other way around as in manufacturing. Each new project therefore demands a new working center. (3) The construction industry includes a wide variety of final products, from small domestic alterations to huge industrial plant, and each one involves a different mixture of heterogeneous activities. So when a firm starts out on a new product, it has to integrate dissimilar intermediate activities. Thus the activities that construction firms carry out are

12 Legal reasons may be relevant in some situations but they are of minor importance in the construction industry during the period of time analyzed (González, Arruñada, and Fernández, 1998).

13 Eccles (1981a, pp. 450-451; and 1981b, pp. 337-338), Ball (1988), Hillebrandt and Cannon (1990) and Masten et al. (1991, pp. 8-10) analyze construction firms and their technology in more detail. 
heterogeneous not only in type but also in geographical location.

The production process in the construction industry is also characterized by the use of relatively low technology and high intensity of labor. ${ }^{14}$ However, it is useful to distinguish two different technological stages in which firms specialize. One focuses on project design and technical management and the other concentrates on project implementation. Each stage requires different capabilities. Design and management are carried out by qualified technical teams having design, supervisory and problem-solving capabilities that enable them to make competitive bids for all kinds of contracts. Implementation activities, on the other hand, require cost control, operative capabilities and knowledge of local labor markets-i.e. opportunity wages, suitable incentive systems, and precise screening mechanisms. These teams are based on blue-collar workers, mainly craftsmen and unskilled laborers, whose purpose is to accurately implement any project.

A final special feature of the construction industry is the relative value of each unit of product. Each project or contract usually represents an important percentage of the transactors' operations. This happens not only in civil engineering, where all projects are large, but also in residential building. In the latter, projects may be of minor economic importance but firms are also smaller in size, so each project again constitutes a substantial percentage of overall sales. We can therefore conclude that the demand for construction firms is of quite a discrete nature (i.e. the sum of only a few products).

\subsection{The Subcontracting Decision}

Immobility and uniqueness of output affect the relative importance of different sources of asset specificity. ${ }^{15}$ First, site specificity is not important because construction

\footnotetext{
14 The classification of construction activities as "low-technology" can be found in Hagedoorn (1993, p. 385) and Masten et al, (1991, p. 22). The consideration of activities as "labor-intensive" can be found in Stinchcombe (1959, p. 168), Thompson (1967, pp. 17-19), Eccles (1981a, pp. 450-451, and 1981b, p. 337), Ball (1988, p. 89), and Masten et al. (1991, p. 10).
}

15 See, for example, Williamson (1996, pp. 59-60). 
assets are mobile and relocating them is relatively inexpensive. Second, physical specificity will depend on the type of construction because the productive assets are usually designed for a particular kind of work or product and not for a particular project. Physical specificity will therefore be directly related to the extent of the market, in indirect proportion to the number of firms that could use the assets. ${ }^{16}$ We expect a similar relationship between the extent of the market and other kinds of specificity problems: the probability of hold-up derived from human capital investments, dedicated assets or temporary specificity will be low when there are many firms offering similar products in a nearby market. The training of bricklayers specializing in residential building, for example, does not seem specific if we consider the great number of firms in which they could work. Other professionals in the industry, however, have fewer opportunities of alternative employment because they specialize in smaller markets. Take, for example, underwater foundations in marine construction.

Uncertainty in construction is almost unrelated to input supply but is related to demand changes. First, given that capital investment is small and technical knowledge widely spread, the risk of technological obsolescence is lower than in manufacturing. Second, suppliers do not have substantial bargaining power-most construction inputs are of a general type and are supplied by competitive industries. ${ }^{17}$ However, the volatility of demand is high because most of the work is obtained on the basis of tenders. ${ }^{18}$ Also, the discrete nature of production, with a few products weighing heavily in the activity of most firms, reduces market liquidity by making supply and demand more difficult to adjust. This increases uncertainty because the activity level of the firm depends not only on tenders but also on just a few contracts.

${ }^{16}$ Eccles also points out the importance of the extent of the market in the subcontracting decisions of construction firms (1981a, pp. 454-456 and 1981b, p. 339).

17 Low capital requirements and easy access to productive factors are the main factors leading consultants to consider entry into the industry as easy. See, for example, Hillebrandt (1989, p. 145) and Ball (1988, p. 52).

18 It has been estimated for some British firms that tendering success rates vary between 17 and 27 per 100 
The immobility and uniqueness of the construction output also lead firms to establish a dual structure. Construction firms have a central unit, which includes the main activities subject to scale economies, and several working centers located where the different projects are being carried out. Monitoring problems caused by this kind of geographical dispersion are one of the explanations for the use of franchising. ${ }^{19}$ Subcontracting to local firms is another way of solving these problems because it reduces the divergence of interests between the construction firm and the actual executors of each project, reducing monitoring costs. Subcontracting has some additional advantages, derived from the continuous relocation of working centers. First, it reduces the displacement expenses of workers and machinery. Second, even if the construction firm tried to have direct access to the local labor market, the subcontractors would enjoy some advantages because they have a previous structure and superior local knowledge of this labor market. We therefore expect a positive relationship between geographical dispersion and subcontracting. ${ }^{20}$

The variety and uniqueness of the output of construction firms require a wide range of intermediate activities. Integration of these activities will demand an extra effort in terms of internal monitoring and coordination, whereas subcontracting reduces the firm's information needs, decreasing monitoring costs. If a firm subcontracts an activity, it only needs to monitor the quality of the output, whereas if the firm vertically integrates such an activity it has to know the details of the production process. Consequently, the more activities a firm has integrated, the more likely it is to outsource any additional activity. Furthermore, the increase in monitoring and coordination costs is probably greater with more heterogeneous activities. Hence, a firm will be more likely to subcontract the tasks which differ most from its main activity, integrating the activities in which it has

(Hillebrandt, 1989, p. 105).

19 Rubin (1978, pp. 226-230) originally develops the argument, which has been extensively tested. See, for example, Brickley and Dark (1987) and Lafontaine (1992).

20 Geographical dispersion has been considered as a determining factor in construction industry organization since Stinchcombe (1959, p. 169). 
comparative advantages for monitoring. We interpret this argument as a contractual explanation for the classic recommendation given in management literature that a firm must focus on what it does best or, in other words, on its core competencies. ${ }^{21} \mathrm{We}$ expect that the greater the number of activities a firm vertically integrates, the lower its likelihood of integrating an additional activity.

The particular core competencies of a firm may also affect its subcontracting policy. Thus, when a firm has mainly intangible resources, such as those specializing in project design and technical management, the sale of services related to its excess capacity is subject to substantial transaction costs because of the informational asymmetry-caused by difficulties in measuring quality, mainly in technical aspects and in the effectiveness of the project management. It can be then expected that the greater the firm's specialization in these activities, the greater the degree of vertical integration.

\section{Empirical tests}

\subsection{Data and variables}

We have tested our hypotheses on a panel of firms in the construction industry over six years (1987-1992). Information was obtained from a survey carried out by the Spanish Ministry of Environment, Transport and Public Works (MOPTMA). ${ }^{22}$ The sample was taken from firms recorded in the Spanish Industry Register whose main activity was construction, including building and civil engineering, and whose business license was that of "general contractor". ${ }^{23}$ However, since for firms employing less than 20 workers a shorter version of the questionnaire was used, we were forced to consider firms above that

\footnotetext{
21 See, for example, Prahalad and Hamel (1990) and Amit and Schoemaker (1993).

22 See survey details in MOPTMA (1994, pp. 175-90).

23 A general contractor is a firm that obtains the project from a property developer and assumes responsibility for finishing the work on time. Normally he takes charge of organizing the production process and hiring the needed workers and firms.
} 
threshold. Restricting the sample only to general contractors ensures that all selected firms play the same organizational role in the production process, regardless of their specialization. Finally, the panel is not balanced because the sample was changed each year and there were some variations in the sample due to random non-responses.

Subcontracting. The dependent variable is the percentage of subcontracting (SUBCO), computed as the ratio of the value of activities subcontracted to other firms in relation to the value of the total production of the firm in question. Subcontracted activities are also classified by type. Each category is an intermediate and distinct step in the building process, and may be typical of one or several kinds of construction output. There are 26 categories, which vary from demolition to industrial installation, including drainage, signaling, insulation, masonry, painting, etc. We have chosen an aggregate measure of subcontracting instead of a percentage for each individual activity because we do not have enough information to compute the latter. Although there is data available on the subcontracted amounts for each of these 26 activities-which will be the numerator in the proposed subcontracting ratio-, it is not possible to determine-whether each amount represents the total value of the firm's activity or, conversely, the firm also carries out the activity on its own -i.e. we do not know the denominator in the proposed subcontracting ratio.

As independent variables, we consider specificity, uncertainty, geographical dispersion, output variety, and technological specialization. Table 3 shows the descriptive statistics of all these variables.

Specificity (SPECIFI) is proxied through an index that aims to estimate the closeness to "small numbers" situations for each firm by measuring the extent of the market for the firm's different types of products. The rationale for this calculation is that if there are many firms building the same product with the same technology — and in the absence of site or physical specificity_, the assets concerned will have many alternative users and will therefore generate small expropriable quasi-rents. Site and physical specificity, being 
situations in which hold-up problems are unrelated to the number of firms employing similar assets, are not important in construction because, as argued above, investments are generally more specific to the kind of product than to the site or a particular project. As hold-up problems seem to be closely related to the size of each product market, the best estimate of the potential for alternative use of assets seems to be the number of firms manufacturing each product. The inverse is therefore a proxy of specificity $\left(e_{k t}\right)$ for each kind of product $k$ :

$$
e_{k t}=\frac{1}{n_{k t}}
$$

where $n_{k t}$ is the number of firms offering product $k$ in year $t$. We have distinguished six kinds of products, following the classification of the official statistics (MOPTMA, 1994, pp. xiv-xv). Construction products are first divided into two main branches: building and civil engineering. Building includes two basic sub-categories: residential and nonresidential. Civil engineering includes four sub-categories: road, railway, marine, and others.

Expression [1] would bias the estimation when at least two circumstances coincide: (1) if there are firms working only in a local area, so that in some areas the number of firms competing will be less than $n_{k t}$ firms; and (2) if, due to information problems, ascertaining opportunities for re-utilizing the asset is less costly at the local than at the national level. Under such circumstances, it might be more suitable to consider only the local market in each geographical area. Consequently, we should not take into account the number of firms working in the country as a whole $\left(n_{k t}\right)$ but rather the number of firms working in each local area. $^{24}$ Unfortunately, the available information is not so detailed, so we have approximated this ideal situation by adjusting the number of firms offering product $k$

\footnotetext{
24 The consideration of provinces (or geographical areas) can help to give an idea of the difficulties of finding an alternative supplier at the local site at short notice (temporary specificity), at least from a spatial point of view (see, Pirrong, 1993, p.942-3).
} 
according to the proportion of the average number of provinces where firms mainly building product $k$ operate in year $t$ over the total number of provinces in Spain. In this way, a second index for the specificity of each kind of product was obtained:

$$
e_{k t}=\frac{1}{n_{k t} \cdot \frac{\bar{a}_{k t}}{A}}
$$

where $\bar{a}_{k t}$ is the average number of provinces where firms mainly building product $k$ (more than 50 per 100 of their output) operate in year $t$ and $A$ is the number of provinces or areas in Spain. ${ }^{25}$ Unlike the first index, this one tends to overestimate the specificity of firms' investments, because it considers a smaller number of firms as potential users of their assets. Considering both indexes simultaneously, one underestimating specificity and the other overestimating it, we obtain an interval where the real value for the specificity of investments made by firms mainly building product $\mathrm{k}$ will lie.

Finally, to estimate each firm's specificity in each year $\left(E_{i t}\right)$, we aggregate the indexes obtained for each of the products built by each firm and weight them with the share of each product in the firm's total production:

$$
p_{i k t}=\frac{P_{i k t}}{\sum_{k=1}^{6} P_{i k t}},
$$

where $P_{i k t}$ indicates production by firm $i$ of product $k$ in year $t$. The final index of specificity for each firm in year $t$ is thus:

$$
E_{i t}=\sum_{k=1}^{6} p_{i k t} \cdot e_{k t}
$$

25 It should be noted that A is constant-i.e. the 52 Spanish provinces - and has no econometric effect (it affects only the quantity of the estimated parameter). 
where $e_{k i}$ can be either expression [2] in which case $E_{i t}$ is called SPECIFIa, or expression [1] in which case $E_{i t}$ we would be called SPECIFIb.

One of the main advantages of our method for measuring hold-up problems is its objectivity - it does not depend on a personal evaluation of alternative uses of a firm's investments. In the absence of data, subjective estimations of specificity have frequently been used in empirical studies. ${ }^{26}$ These estimations are based on the opinions of managers and technicians, obtained through direct interviews or in other indirect ways, ${ }^{27}$ but this could create problems because individuals might have different judgements on assets specificity. ${ }^{28}$ A second advantage is that it relates to the hold-up concept itself. Sometimes, engineering effort has been used to estimate specificity in empirical studies, especially in the automobile industry. ${ }^{29}$ This aims to take into account the know-how generated during the development of new products or components. However, this variable has been dismissed in recent empirical works because it includes only a limited aspect of specificity and is biased by the expertise in managing engineering-intensive activities that such firms acquire over the years. Hence, the engineering effort is more a reflection of management proficiency than of changes in the risk of hold-up. ${ }^{30}$

As is common in empirical studies on transaction costs, our hold-up index is not problem-free. Even if we can distinguish six kinds of products (MOPTMA, 1994, pp. xiv$\mathrm{xv}$ ), this measurement method does not reflect the existence-within each category-of specialized works that require more specific investments than usual. However, as the main

\footnotetext{
26 Minkler and Park (1994, p. 411 and 415) also point out this drawback in asset specificity measures.

27 See, for example, Anderson and Schmittlein (1984, p. 390), Masten et al. (1989, p. 269 and 1991, p. 12) and Zaheer and Venkatraman (1995, p. 382).

28 For example, Masten et al. (1991, p. 12), after finding certain disparities between the firm's response and an independent technician's response-which was used as a control device-rejected the technician's opinion, arguing that he was less informed about the firm's assets.

29 See Monteverde and Teece (1982), and Masten et al. (1989).

30 See Masten et al. (1991, p. 22) for a further discussion.
} 
consequence is underestimation of the importance of specificity, if our measure is significant, a more accurate one will also be significant. ${ }^{31}$ Furthermore, our index cannot differentiate, as we would have liked, a postcontractual small numbers situationspecificity strictu senso-from a precontractual monopoly. However, in our case, this problem is not significant because the absence of barriers to entry diminishes the relevance of market concentration as an indicator of market power.

Uncertainty. We have used more conventional measurements for the rest of the variables. In keeping with previous works on the construction industry, ${ }^{32}$ we have computed uncertainty (UNCERTA) as the annual average of the absolute value of quarterly variations in the number of the firm's workers with respect to the previous month:

$$
U_{i t}=\frac{1}{3} \cdot \sum_{j=1}^{3} \mid\left(\frac{q_{i j+1}}{q_{i j}}-1\right)
$$

where $q_{i j}$ is the number of workers hired by firm $i$ in quarter $j$ adjusted for a seasonal index. ${ }^{33}$

Homogeneity in transactions. This has been estimated by means of two variables that measure geographical dispersion (GEODIS) and diversity of output (PRDVAR). The GEODIS variable indicates the number of provinces (from one to 52) in which a firm

31 As a control test, we distinguished between new building and renovation for each kind of product. The results did not show substantial differences.

32 See Shelanski and Klein (1995, pp. 342-4) for a general discussion of the main measures of uncertainty used in contractual empirical studies, and Stinchcombe (1959) and Eccles (1981a) for specific measures in the construction industry.

33 Since the construction industry may be seasonal, we have estimated seasonal indexes for the whole industry to remove the potential seasonal variations from the number of employees hired by construction firms. Following the technique recommended by Pindyck and Rubinfeld (1991, pp.432-4), we have found a very weak seasonal effect, always lower than $1.5 \%$. In addition, we have checked that this variable was not related to the economic cycle. We have not found statistically significant differences between the two stages of economic growth. 
works. The PRDVAR variable indicates the number of different tasks that the firm takes on. This number goes from 1 to 12 because each of the six categories in construction products has been divided into two sub-categories, namely renovation and new building. Even though the technology is quite similar, the execution and control of these two kinds of product differs.

Intangible assets. This hypothesis is not directly testable because we cannot observe the degree of subcontracting in design and technical management. ${ }^{34}$ However, it can be tested indirectly. Firms specializing in design and technical management can avoid suboptimal use of their resources in two different ways. Firstly, they can try to obtain new projects to use up all their capacity but this creates an additional problem. New projects include many different activities in which technical firms are not interested, such as implementation activities. An obvious solution is to subcontract these activities to specialized subcontractors and concentrate all efforts on those activities in which they have a competitive advantage. Secondly, technical firms can work as subcontractors of other firms that have new projects, carrying out design and technical management. However, this solution is unlikely because the intangible assets involved in the transaction provoke high transaction costs. Therefore, if we find a positive relationship between specialization in technical activities and subcontracting of implementation activities, we would indirectlyfollowing the above assumptions - test the hypothesis of a positive relationship between specialization in intangible resources and vertical integration of the activities in which they are necessary. Otherwise, we could reject the hypothesis of the influence of intangible resources. We have measured specialization in technical activities (INTANG) as the percentage of the firm's annual sales coming from selling services related to studies, projects and research in architecture, engineering, and supervision.

34 This is because our measure of subcontracting only includes implementation activities. 


\subsection{Methodology and results}

We have estimated a multivariate regression model with the panel of construction firms to test our hypotheses. Empirically, our model can be summarized as follows:

$$
S_{i t}=X_{i t} \beta+\lambda_{t}+\varepsilon_{i t}
$$

where $S_{i t}$ is the degree of subcontracting of firm $i$ at time $t, \lambda_{t}$ are dummy variables that reflect variation over time, and $X_{i t}$ is the set of regressors previously explained. The sign of $\beta$ is expected to be as described in Table 2. If we assume that the error term is independent of $\mathrm{X}$, this model can be estimated by ordinary least squares (OLS). Table 4 shows the results of this estimation, which could be directly comparable to previous cross-sectional evidence in vertical integration. ${ }^{35}$ Subcontracting tends to decrease as hold-up problems grow and to increase with the number of provinces in which the firm operates, its diversity of output, and its degree of specialization in design and technical management. Uncertainty does not seem to have significant effects on subcontracting. Finally, although all the regressions presented in Table 4 contain year dummies for the reporting year for each observation, they are not shown because none of them is significant.

This estimation, however, does not control for the unobservable heterogeneity, which is the main advantage of panel data. We then assume that the unobservable error term $\varepsilon_{i t}$ is:

$$
\varepsilon_{i t}=\alpha_{i}+\mu_{i t}
$$

where $\alpha_{i}$ is a firm-specific component that reflects unobservable heterogeneity-that is to say, all the features that are identical in all the observations of a particular firm and that we have not been able to measure. It is possible to think of $\alpha_{i}$ as the "management style" of the firm, a broad term which includes the effectiveness of its managers, the quality of its

35 These results should be considered merely as a guideline and summary of the six annual cross-sectional results-estimations are inefficient because the error terms are not iid. Cross-sectional results are available upon request. 
output, its competitive strategy, etc. Finally, $\mu_{i t}$ is the common stochastic error.

Following these assumptions, the most suitable estimators depend on the nature of the relationship between individual effects $\left(u_{i}\right)$ and regressors. In our case, the "management style" of the firm should probably be correlated with, for example, the number of provinces in which the firm operates or with its technological specialization. For the best managed firms, it is probably easier to expand to other markets and to acquire complex technologies. Therefore, if individual effects and regressors are correlated, a fixed effects model should be estimated. Such a model takes all the variables as differences from their time-series means, so the bias due to correlation is eliminated $-u_{i}$ does not vary over time. However, a model in which it is assumed that regressors and individual effects are orthogonal, estimated then as a random effect model, would be preferable because estimations are more efficient. To statistically determine the most suitable estimator, the orthogonality of the random effects and the regressors has been tested. We have used the Hausman (1978) test, which is based on the idea that under the null hypothesis of non-correlation, both the "within" group estimator (WGE) and the generalized least squared (GLS) estimator are consistent, but the WGE is inefficient. Since the two estimates should not differ systematically, a test can be conducted on this difference. ${ }^{36}$ The results obtained in these tests lead us to reject the null hypothesis of non-correlation in all the models estimated, always at a significance level of $8 \%$ or lower. Hence, we have chosen a fixed effects model.

Table 5 shows the fixed effect results. ${ }^{37}$ After controlling for unobserved heterogeneity, there is no change in the significance and sign of hold-up problems, the output variety, and the specialization in technical and management tasks. However, two estimations do change substantially. First, the direct effect of uncertainty is significant, whereas the interactive effect is not. Second, the geographical dispersion parameter is not

\footnotetext{
36 See Greene (1993, pp. 479-80) for a further discussion of this methodology and additional references.

37 The result of the Hausman test supporting the use of fixed effects rather than random effects in the complete model (fifth column) is $\chi_{13}^{2}=52.21$.
} 
significantly different from zero. Time effects, on the other hand, are significant and negative in the first three years, meaning that the average degree of subcontracting in construction firms is lower than in the reference year (1992).

Finally, as the dependent variable is limited between 0 and 1, the functional form to estimate has to be consistent with this constraint. This is the case, for example, of a logistic functional form, where:

$$
S_{i t}=\frac{e^{\alpha_{i}+X_{i t} \beta+\lambda_{t}+\mu_{i t}}}{1+e^{\alpha_{i}+X_{i t} \beta+\lambda_{t}+\mu_{i t}}}
$$

Taking logarithms and re-ordering the expression, we can estimate the following model by OLS:

$$
\log \left(\frac{S_{i t}}{1-S_{i t}}\right)=\alpha_{i}+X_{i t} \beta+\lambda_{t}+\mu_{i t}
$$

In Table 6, we combine and compare the results obtained using a logistic and linear functional form and the two specificity indexes. We find, first, that the two functional specifications lead to very similar results, with just one exception: the effect of uncertainty, which is not significant when the logistic functional form is used. Second, both specificity indexes are significant, irrespective of the functional form considered.

\subsection{Discussion}

First, it is worth noting that the indexes we have proposed as estimators of hold-up problems have the expected sign and are significant, even after controlling for unobservable heterogeneity and considering a logistic functional form. Furthermore, the stability of the coefficients across different specifications indicates the robustness of the results and suggests the lack of problems of collinearity with some other variables. As both indexes of specificity are significant and negative, the actual effect of specificity probably lies between the two extremes defined by the indexes. 
However, these results do not guarantee that the indexes reflect hold-up problems exclusively - they may reflect both ex ante and ex post monopoly situations. They are therefore suitable measures of specificity only in those situations where the possibility of ex ante monopoly can be dismissed. Several items of empirical evidence suggest that this is indeed our case. First, previous technological studies conclude that construction technology is low or basic (see footnote 14), so that technology could hardly constitute a serious barrier to entry. Second, the legal requirements that firms must satisfy to enter public bids do not seem to seriously constrain competition in the bidding process. In 1996, the average final prices of construction contracts awarded were 24.3 per 100 lower than the initial estimated price, and the average number of bidders was 21.4 (Seopan, 1997, pp. 2021, and Table 14). Furthermore, such requirements can also be met by means of a "temporary alliance" of two or more firms - a common legal figure in Spain termed "Unión Temporal de Empresas' (UTE).

Results regarding uncertainty are not so conclusive, however, because coefficients are not statistically significant. Even if in some estimations we obtain significant (negative) parameters, results consistently show a lack of significance once we specify a logistic functional form as a way of solving the problem of limiting the dependent variable between 0 and 1.38 An obvious reason for this lack of significance is that the estimator of uncertainty may be inaccurate. We are inclined to think, however, that the opposing effects of uncertainty on subcontracting offset each other. On the one hand, uncertainty raises the cost of market contracting because it increases the difficulties in foreseeing trends in the relevant variables. On the other hand, uncertainty makes opportunism easier with vertical integration than with subcontracting, because the latter provides more powerful incentives. In addition, as all the tasks included in our estimation of subcontracting are necessary in the different construction products, a high positive correlation between the tasks and the main activity of the firms in our sample-namely, construction-should be expected. If

38 Other regressions with different specifications were carried out to check whether these results were due to 
managers wish to reduce the impact of uncertainty in their firms, they will tend to externalize (subcontract) such activities, integrating other, less correlated, tasks. However, there are differences in the value of this correlation due to differences in firms' specialization-some tasks are less related to the main activity than others. As the information required to control for this effect is not available and such an effect is probably specific to each firm, its influence appears aggregated to the individual effects. This would indicate the possible bias of cross-sectional estimations and could also explain why results about uncertainty vary so much across such studies-i.e. when firm-specific effects are not considered. In fact, a good number of cross-sectional empirical studies have obtained contradictory results concerning the influence of uncertainty on vertical integration decisions. ${ }^{39}$ Finally, our results do not reveal any significant interaction between specificity and uncertainty either.

The variety of products offered by construction firms, which is the first of the variables for estimating monitoring costs, is significant in all the models. As the variety of products widens, subcontracting grows, although at a decreasing rate. This finding supports our hypothesis that an increase in the variety of products complicates internal monitoring and coordination, making subcontracting more attractive. This result can also be seen as a confirmation of the resources and capabilities theory. In general, the more the knowledge for managing new tasks differs from the knowledge required for the firm's core competencies, the greater the monitoring and coordination costs. Therefore, firms will tend to focus on their core activities, subcontracting other tasks.

Geographical distribution of activities, which is the second variable for estimating collinearity problems, but the results obtained were never statistically significant for the variable UNCERTA.

39 Many studies find a significant positive relation between uncertainty and the degree of vertical integration. See, for example, Masten (1984), Levy (1985), MacMillan, Hambrick, and Pennings (1986), and Masten et al. (1991). A non-significant or negative relationship is found by Stinchcombe (1959), Eccles (1981a), Anderson and Schmittlein (1984), Balakrishnan and Wernerfelt (1986), Walker and Weber (1987), Caves and Bradburd (1988), Harrigan (1985 and 1986), and Zaheer and Venkatraman (1995). 
monitoring costs, is significant in cross-sectional estimations but not in the panel estimations. This result suggests that cross-sectional estimations are biased upwards. Actually, subcontracting does not seem to be affected by the geographical dispersion of tasks but by the individual effects $\left(\alpha_{i}\right)$, which we have called "management style". For example, a management style resulting from an underlying geographical expansion strategy will subcontract some tasks at the beginning of its operations in each new location because the firm needs to develop a local infrastructure and to learn about local markets before integrating a new task. This could justify a positive relationship between individual effects and geographical dispersion.

Finally, technological specialization and subcontracting are positively and significantly related. Given that our measure of subcontracting only reflects implementation activities, this was the expected result. As firms specialize in design activities and technical management, they subcontract more implementation activities. Our explanation is that firms specializing in design activities and technical management find it difficult to market their idle capacity due to the intangibility of the firm's assets and the high transaction costs they generate. Therefore, such firms need to operate as a general contractor working in the activities they do best, subcontracting the rest. However, we are not able to test this hypothesis directly so other unknown factors could be relevant.

Year dummy variables are significant only in the first three years. Considering the trends of the construction industry during that period, this result is unexpected. Figure 1 shows that the growth of the construction industry output was positive every year but the last (1992). If firms subcontract because of a lack of capacity, we should find a decrease in subcontracting in 1992. However, we find just the opposite: subcontracting was greater in 1992 than in any other year. These findings are consistent with the fact that the technology of the construction industry is low and labor-intensive. Therefore, when demand grows, what firms fundamentally need is more labor. Firms specializing in implementation recruit the new workers they need directly from the labor market, rather than increasing subcontracting. This might explain why the variability in the number of workers employed 
in the construction industry is greater than in other activities ${ }^{40}$ in that one of the core competencies of such firms is to have a good knowledge of local labor markets. One plausible explanation for the significance of time effects in the first three years is the existence of an upward trend in subcontracting policy, which is probably due to changes in the Spanish labor market regulation at the end of the 1970s. ${ }^{41}$ Decreasing parameters of year dummies corroborate such a hypothesis.

\section{Conclusions}

This work analyzes factors determining the degree of subcontracting, using evidence from the construction industry. We develop a set of hypotheses mainly based on contractual theories, although some arguments are close to the resources and capabilities theory.

We argue, first, that a higher risk of hold-up reduces subcontracting because vertical integration is better at solving the quasi-rents expropriation problem. We test this hypothesis by means of two new indexes that estimate the specificity of each firm's investments. The indexes are based on the market size of each of the different products built by the firm and—contrary to previous measures - are independent of the managerial assessment of the assets. Second, we examine the different effects of uncertainty, because theory generates contradictory hypotheses about its influence on subcontracting. This may

40 Quarterly variations in labor are greater in construction than in any other activity. The following table compares standard deviations of quarterly variations in labor (from 1976 to 1992) in construction with three other activities.

\begin{tabular}{lcccc}
\hline & Construction & $\begin{array}{c}\text { Manufacturing } \\
\text { and energy }\end{array}$ & Services & Economy \\
\cline { 2 - 5 } & 0.359 & 0.009 & 0.013 & 0.09 \\
Standard Deviation & & $39.930^{* * *}$ & $32.112^{* * *}$ & $35.600^{* * * *}$ \\
$\begin{array}{l}\text { Leven's Test for equality of } \\
\text { variance (against construction) }\end{array}$ & & & \\
***: Significant at 0.01. Source: INE (1977-1993). & &
\end{tabular}

41 For further details, see González, et al. (1998). 
depend on the intensity of the change with respect to initial conditions, on the direction of the correlation between subcontracted activities and the main activity, and on the interactive effect between uncertainty and specificity. Third, we estimate the influence of monitoring costs through the geographical dispersion of activities, variety of products, and investments in intangible assets. Geographical dispersion reduces vertical integration because, given the dual technology typical of the construction industry, it generates high monitoring costs. The variety of products offered by construction firms increases subcontracting because it complicates internal monitoring and coordination-firms vertically integrate core activities and subcontract the rest. Lastly, investments in intangible assets increase vertical integration because the costs of monitoring activities where such assets are required are particularly high, making them difficult to market.

We have tested our hypotheses on a panel of 278 Spanish construction firms observed from 1987 to 1992. The use of a panel allowed us to control for unobservable heterogeneity, improving estimations, and to test hypotheses that could not be tested in a cross-sectional study. The results showed, first, that firms tend to subcontract fewer tasks when the hold-up risk is higher. The proposed specificity indexes proved useful as estimators of hold-up problems in industries, such as construction, where neither the market power of the firms nor the site and physical asset specificity are significant. Second, uncertainty does not show any statistically significant effect on subcontracting. We conjecture that this is because opposing effects outweigh each other. Further research, employing more precise measures of uncertainty, is required to differentiate these effects. Third, subcontracting grows as the number of different products built by the firm and its specialization in design and technical management increase. However, the effect of geographical dispersion is not significant, despite being significant in the cross-sectional analysis. This result suggests that monitoring problems connected with geographical dispersion depend more on the particular firm than on the number of areas in which the firm operates. A possible explanation is that the specific management style could overcome the increase in monitoring costs due to geographical dispersion. Finally, our results do not support the conjecture that firms tend to subcontract more activities to resolve 
temporary shortages of capacity. A plausible explanation for this finding is that firms adjust their capacity to changes in demand through some "internal" mechanism, continuously hiring and firing workers.

\section{References}

Amit, R. and P. Schoemaker, 1993, "Strategic Assets and Organizational Rent," Strategic Management Journal, 14, pp. 33-46.

Anderson, E., 1985, "The Salesperson as Outside Agent or Employee: A Transaction Cost Analysis," Marketing Science, 4, pp. 234-54.

Anderson, E. and D. Schmittlein, 1984, "Integration of the Sales Force: An Empirical Examination," Rand Journal of Economics, 15, pp. 385-95.

Balakrishnan, S. and B. Wernerfelt, 1986, "Technical Change, Competition and Vertical Integration," Strategic Management Journal, 7, pp. 347-59.

Ball, M., 1988, Rebuilding Construction: Economic Change in the British Construction Industry, Routledge, London.

Barzel, Y., 1989, Economic Analysis of Property Rights, Cambridge University Press, New York.

Brickley, J. A. and F. H. Dark, 1987, "The Choice of Organizational Form: The Case of Franchising," Journal of Financial Economics, 18, pp. 401-20.

Caves, R. E. and R. M. Bradburd, 1988, "The Empirical Determinants of Vertical Integration," Journal of Economic Behavior and Organization, 9, pp. 265-79.

Coase, R. H., 1937, “The Nature of the Firm," Economica, 4, pp. 386-405, reprint in R. H. Coase, The Firm, the Market and the Law, University of Chicago Press, Chicago, 1988, pp. 33-55.

Eccles, R. G., 1981a, "Bureaucratic Vs. Craft Administration: The Relationship of Market Structure to the Construction Firm," Administrative Science Quarterly, 26, pp. 449-69.

Eccles, R. G., 1981b, "The Quasifirm in the Construction Industry," Journal of Economic Behavior and Organization, 2, pp. 335-57.

Foss, N. J., 1997, Resources, Firms and Strategies. A Reader in the Resource-Based Perspective, Oxford University Press, Oxford.

Goldberg, V., 1980, "Relational Exchange: Economics and Complex Contracts" American Behavioral Scientist, 23, pp. 337-52.

González, M., B. Arruñada and A. Fernández, 1997, "La decisión de subcontratar: el caso de las empresas constructoras" Investigaciones Económicas, 21, pp. 503-524. 
González, M., B. Arruñada and A. Fernández, 1998, "Regulation as a Cause of Firm Fragmentation: The Case of Spanish Construction Industry," International Review of Law and Economics, 18, pp. 433-450.

Grant R. W., 1991, “The Resource-Based Theory of Competitive Advantage: Implications for Strategy Formulation" California Management Review, 33, pp. 114-135.

Greene, W. H., 1993, Econometric Analysis, 2nd. edition, Prentice Hall, Englewood Cliffs.

Grossman, S. J. and O. D. Hart, 1986, "The Costs and Benefits of Ownership: A Theory of Vertical and Lateral Integration," Journal of Political Economy, 94, pp. 691-719.

Hagedoorn, J., 1993, "Understanding the Rationale of Strategic Technology Partnering: Interorganizational Modes of Cooperation and Sectoral Differences," Strategic Management Journal, 14, pp. 371-385.

Harrigan, K. R., 1985, "Vertical Integration and Corporate Strategy," Academy of Management Journal, 28, pp. 397-425.

Harrigan, K., R., 1986, "Matching Vertical Integration Strategies to Competitive Conditions," Strategic Management Journal, 7, pp. 535-55.

Hart, O. and J. Moore, 1990, "Property Rights and the Nature of the Firm," Journal of Political Economy, 98, pp. 1119-58.

Hausman, J., 1978, “Specification tests in Econometrics,” Econometrica, 46, pp. 1251-71.

Hillebrandt, P. M., 1989, Economic Theory and the Construction Industry, 2nd. Ed. MacMillan, Basingstoke.

Hillebrandt, P. M. and J. Cannon, 1990, The Modern Construction Firm, MacMillan, London.

Instituto Nacional de Estadística (INE), 1977-1993, Encuesta de Población Activa, INE, Madrid.

Joskow, P. L., 1988, "Asset Specificity and the Structure of Vertical Relationships: Empirical Evidence," Journal of Law, Economics and Organization, 4, pp. 95117.

Klein, B., 1996, "Why Hold-ups Occur: The Self-Enforcing Range of Contractual Relationship" Economic Inquiry, 34, pp. 444-63.

Klein, B., R. G. Crawford and A. A. Alchian, 1978, "Vertical Integration, Appropriable Rents, and the Competitive Contracting Process," Journal of Law and Economics, 21, pp. 297-326.

Klein, B. and K. Murphy, 1997, "Vertical Integration as a Self-Enforcing Contractual Arrangement," American Economic Review, 87, pp. 415-420.

Lafontaine, F., 1992, "Agency Theory and Franchising: Some Empirical Results," Rand Journal of Economics, 23, pp. 263-83. 
Lafontaine, F., 1993, "Contractual Arrangements as Signaling Devices: Evidence from Franchising, Journal of Law, Economics and Organization, 9, pp. 256-89.

Lafontaine, F. and K. L. Shaw, 1997, "The Dynamics of Franchise Contracting: Evidence from Panel Data," NBER Working Paper Series, n. 5585.

Levy, D. T., 1985, “The Transaction Cost Approach to Vertical Integration: An Empirical Examination," Review of Economics and Statistics, 67, pp. 438-45.

Lieberman, M. B., 1991, "Determinants of Vertical Integration: An Empirical Test," Journal of Industrial Economics, 39, pp. 451-66.

MacMillan, I. C., D. C. Hambrick y J. M. Pennings, 1986, "Uncertainty Reduction and the Threat of Supplier Retaliation: Two Views of the Backward Integration Decision," Organization Studies, 7, pp. 263-78.

Macneil, I. R., 1978, "Contracts: Adjustment of Long-term Economic Relations under Classical, Neoclassical and Relational Contract Law," Northwestern University Law Review, 72, pp. 854-906.

Masten, S. E., 1984, "The Organization of Production: Evidence from the Aerospace Industry," Journal of Law and Economics, 23, pp. 403-17.

Masten, S. E., J. W. Meehan Jr. and E. A. Snyder, 1989, "Vertical Integration in the U.S. Auto Industry: A Note on the Influence of Transaction Specific Assets," Journal of Economic Behavior and Organization, 12, pp. 265-73.

Masten, S. E., J. W. Meehan Jr. and E. A. Snyder, 1991, "The Costs of Organization," Journal of Law, Economics and Organization, 7, pp. 1-25.

Masten, S. E. and E. A. Snyder, 1993, "United States v.United Shoe Machinery Corporation," Journal of Law and Economics, 36, pp. 33-70.

Minkler A. P. and T. A. Park, 1994, "Asset Specificity and Vertical Integration in Franchising," Review of Industrial Organization, 9, pp. 409-423.

Monteverde, K and D. J. Teece, 1982, "Supplier Switching Costs and Vertical Integration in the Automobile Industry," The Bell Journal of Economics, 13, pp. 206-13.

MOPTMA, 1994, Estructura de la Construcción: 1980-1991, Series estadísticas, Centro de Publicaciones de la Secretaría General Técnica del MOPTMA, Madrid.

Penrose E.T., 1959, The Theory of the Growth of the Firm, Oxford University Press, Oxford.

Perry, M. K., 1982, "Vertical Integration by Competitive Firms: Uncertainty and Diversification," Southern Economic Journal, 49, pp. 201-8.

Pindyck, R. S. and D. L. Rubinfeld, 1991, Econometric Models and Economic Forecasts, $3^{\text {rd }}$ ed., McGraw-Hill, New York.

Pirrong, S. C., 1993, "Contracting Practices in Bulk Shipping Markets: A Transaction Cost Explanation," Journal of Law and Economics, 36, pp. 937-76. 
Poppo, L. and T. Zenger, 1998, "Testing Alternative Theories of the Firm: Transaction Cost, Knowledge-Based, and Measurement Explanations for Make-or-Buy Decisions in Information Services," Strategic Management Journal, 19, pp.85377.

Prahalad, C. K. and G. Hamel, 1990, "The Core Competence of the Corporation," Harvard Business Review, May-June, pp. 79-91.

Ricketts, M., 1994, The Economics of Business Enterprise: An Introduction to Economic Organization and the Theory of the Firm, second edition, Harvester Wheatsheaf, New York.

Rubin, P., 1978, "The Theory of the Firm and the Structure of the Franchise Contract," Journal of Law and Economics, 21, pp. 223-33.

SEOPAN, 1993, Informe sobre la construcción 1992, SEOPAN, Madrid.

SEOPAN, 1997, Informe sobre la construcción 1996, SEOPAN, Madrid.

Shelanski, H. A. and P. G. Klein, 1995, "Empirical Research in Transaction Cost Economics: A Review and Assessment," Journal of Law, Economics and Organization, 11, pp. 335-61.

Stinchcombe, A. L., 1959, "Bureaucratic and Craft Administration of Production: A Comparative Study," Administrative Science Quarterly, 4, pp. 168-87.

Stuckey, J. and D. White, 1993, "When and When Not to Vertically Integrate," Sloan Management Review, 34, pp. 71-83

Thompson, J. D., 1967, Organizations in Action, McGraw-Hill, New York.

Walker, G. and D. Weber, 1984, "A Transaction Cost Approach to Make-or-Buy Decisions," Administrative Science Quarterly, 30, pp. 373-91.

Walker, G. and D. Weber, 1987, "Supplier Competition, Uncertainty, and Make-or-Buy Decisions," Academy of Management Journal, 29, pp. 589-96.

Williamson, O. E., 1971, "The Vertical Integration of Production: Market Failure Considerations," American Economic Review, 61, pp. 112-23.

Williamson, O. E., 1975, Markets and Hierarchies: Analysis and Antitrust Implications, Free Press, New York.

Williamson, O. E., 1979, "Transaction-Cost Economics: The Governance of Contractual Relations," Journal of Law and Economics, 22, pp. 233-61.

Williamson, O. E., 1985, The Economic Institutions of Capitalism, Free Press, New York.

Williamson, O. E., 1996, The Mechanisms of Governance, Oxford Univeristy Press, New York. 
Zaheer, A. and N. Venkatraman, 1995, "Relational Governance as an Interorganizational Strategy: an Empirical Test of the Role of Trust in Economic Exchange," Strategic Management Journal, 16, pp. 373-92. 


\section{Figures and Tables}

Table 1. Annual Construction GDP Growth in Spain (percentage)

\begin{tabular}{cc}
\hline Year & GDP Growth \\
\hline 1987 & $8.33 \%$ \\
1988 & $10.47 \%$ \\
1989 & $13.81 \%$ \\
1990 & $10.30 \%$ \\
1991 & $3.73 \%$ \\
1992 & $-5.04 \%$ \\
\hline
\end{tabular}

Source: SEOPAN (1993).

Table 2. Summary of Main Hypotheses

\begin{tabular}{|c|c|}
\hline Hypotheses & $\begin{array}{c}\text { Incidence on the } \\
\text { subcontracting decision }\end{array}$ \\
\hline $\begin{array}{l}\text { Hold-up problems } \\
\text { (Specificity) }\end{array}$ & Negative (-) \\
\hline Uncertainty & Null (?) \\
\hline $\begin{array}{l}\text { Interaction between } \\
\text { specificity and uncertainty }\end{array}$ & Negative (-) \\
\hline Output dissimilarity & Positive (+) \\
\hline Geographical dispersion & Positive (+) \\
\hline Intangible assets & $\begin{array}{l}\text { Negative }(-)^{\dagger} \\
\text { Positive }(+)^{\ddagger}\end{array}$ \\
\hline Shortage of capacity & Positive (+) \\
\hline
\end{tabular}


Table 3. Descriptive Statistics of Variables

\begin{tabular}{llcccc}
\hline \multicolumn{1}{c}{ Variable } & Cases & Mean & Std. Dev. & Minimum & Maximum \\
\hline SUBDO & 1,010 & 0.2147 & 0.1773 & 0.0000 & 0.9538 \\
SPECIFla & 1,010 & 0.0323 & 0.0263 & 0.0122 & 0.4435 \\
SPECIFIb & 1,010 & 0.0013 & 0.0010 & 0.0004 & 0.0100 \\
UNCERTA & 1,010 & 0.1113 & 0.1166 & 0.0066 & 1.4554 \\
PRDVAR & 1,010 & 3.0257 & 2.0895 & 1.0000 & 12.0000 \\
GEODIS & 1,010 & 3.2069 & 6.4143 & 1.0000 & 51.0000 \\
INTANG & 1,010 & 0.0008 & 0.0075 & 0.0000 & 0.1527 \\
\hline
\end{tabular}

Table 4. OLS estimations

\begin{tabular}{|c|c|c|c|c|c|}
\hline Variable & $\begin{array}{c}\text { Coefficient } \\
(t=b / \text { s.e. })\end{array}$ & $\begin{array}{c}\text { Coefficient } \\
(t=b / s . e .)\end{array}$ & $\begin{array}{c}\text { Coefficient } \\
\text { (t=b/s.e.) }\end{array}$ & $\begin{array}{c}\text { Coefficient } \\
(t=b / s . e .)\end{array}$ & $\begin{array}{c}\text { Coefficient } \\
(t=b / \text { s.e. })\end{array}$ \\
\hline Constant & $\begin{array}{c}0.2631 \\
(15375) \star \star \star\end{array}$ & $\begin{array}{c}0.2657 \\
(15048) \star \star *\end{array}$ & $\begin{array}{c}0.2625 \\
(15328)^{\star * \star}\end{array}$ & $\begin{array}{c}0.2618 \\
(14341 \text { ) }\end{array}$ & $\begin{array}{c}0.2149 \\
(9752) \star \star *\end{array}$ \\
\hline SPECIFla & $\begin{array}{c}-1.3081 \\
(-5.982)^{\star \star \star}\end{array}$ & $\begin{array}{c}-1.3004 \\
(-5.935)^{\star \star \star}\end{array}$ & $\begin{array}{c}-1.1867 \\
(-4.764)^{\star \star \star}\end{array}$ & $\begin{array}{c}-1.1776 \\
(-4.455)^{\star \star \star}\end{array}$ & $\begin{array}{c}-1.5223 \\
(-5.773)^{\star \star \star}\end{array}$ \\
\hline UNCERTA & & $\begin{array}{l}-0.0282 \\
(-0.595)\end{array}$ & & $\begin{array}{l}0.0065 \\
(0.104)\end{array}$ & $\begin{array}{l}0.0292 \\
(0.474)\end{array}$ \\
\hline UNCE*SPECla & & & $\begin{array}{l}-0.8387 \\
(-1.018)\end{array}$ & $\begin{array}{l}-0.9140 \\
(-0.832)\end{array}$ & $\begin{array}{l}-0.9726 \\
(-0.907)\end{array}$ \\
\hline PRDVAR & & & & & $\begin{array}{c}0.0163 \\
(2.019)^{\star \star}\end{array}$ \\
\hline PRDVAR2 & & & & & $\begin{array}{l}-0.0006 \\
(-0.653)\end{array}$ \\
\hline GEODIS & & & & & $\begin{array}{c}0.0075 \\
(3.195)^{\star \star \star}\end{array}$ \\
\hline GEODIS2 & & & & & $\begin{array}{l}-0.0001 \\
(-1.488)\end{array}$ \\
\hline INTANG & & & & & $\begin{array}{l}1.2907 \\
(1.795)^{*}\end{array}$ \\
\hline$N$ & 1,010 & 1,010 & 1,010 & 1,010 & 1,010 \\
\hline$R^{2}$ & 0.3865 & 0.0390 & 0.0396 & 0.0397 & 0.0967 \\
\hline SSR & 30.4909 & 30.4081 & 30.4594 & 30.4591 & 28.6491 \\
\hline$F$ & $6.72^{\star \star *}$ & $5.81^{\star \star \star}$ & $5.91^{\star \star *}$ & $5.17^{\star \star *}$ & $8.20^{\star \star \star}$ \\
\hline
\end{tabular}

Significance levels: $*$ at $0.10 ; * *$ at $0.05 ; * * *$ at 0.01 . Asymptotic $\mathrm{t}$-values in parentheses. 
Table 5. Panel Estimations

\begin{tabular}{|c|c|c|c|c|c|}
\hline Variable & $\begin{array}{c}\text { Coefficient } \\
(t=b / s . e .)\end{array}$ & $\begin{array}{c}\text { Coefficient } \\
(t=b / s . e .)\end{array}$ & $\begin{array}{c}\text { Coefficient } \\
(t=b / s . e .)\end{array}$ & $\begin{array}{l}\text { Coefficient } \\
(t=b / s . e .)\end{array}$ & $\begin{array}{c}\text { Coefficient } \\
(t=b / s . e .)\end{array}$ \\
\hline SPECIFla & $\begin{array}{c}-0.2150 \\
(-1.999)^{\star \star}\end{array}$ & $\begin{array}{c}-0.2060 \\
(-1.905)^{\star}\end{array}$ & $\begin{array}{l}-0.1632 \\
(-1.311)\end{array}$ & $\begin{array}{c}-0.2190 \\
(-1.814)^{\star}\end{array}$ & $\begin{array}{c}-0.2034 \\
(-1.688)^{\star}\end{array}$ \\
\hline UNCERTA & - & $\begin{array}{c}-0.0596 \\
(-2.032)^{\star \star}\end{array}$ & - & $\begin{array}{c}-0.0632 \\
(-2.116)^{\star \star}\end{array}$ & $\begin{array}{c}-0.0561 \\
(-1.900)^{*}\end{array}$ \\
\hline UNCE*SPECla & - & - & $\begin{array}{l}-0.4714 \\
(-1.020)\end{array}$ & $\begin{array}{l}0.1233 \\
(0.409)\end{array}$ & $\begin{array}{l}0.0505 \\
(0.165)\end{array}$ \\
\hline PRDVAR & - & - & - & - & $\begin{array}{c}0.0203 \\
(2.280)^{\star \star}\end{array}$ \\
\hline PRDVAR2 & - & - & - & - & $\begin{array}{c}-0.0016 \\
(-2.026)^{\star *}\end{array}$ \\
\hline GEODIS & - & - & - & - & $\begin{array}{l}-0.0026 \\
(-1.020)\end{array}$ \\
\hline GEODIS2 & - & - & - & - & $\begin{array}{l}0.0000 \\
(0.969)\end{array}$ \\
\hline INTANG & - & - & - & - & $\begin{array}{c}1.6045 \\
(3.570)^{\star \star \star}\end{array}$ \\
\hline$T 87$ & $\begin{array}{c}-0.0306 \\
(-3.022)^{\star \star \star}\end{array}$ & $\begin{array}{c}-0.0299 \\
(-2.954)^{\star \star \star}\end{array}$ & $\begin{array}{c}-0.0304 \\
(-3.008)^{\star \star \star}\end{array}$ & $\begin{array}{c}-0.0299 \\
(-2.952)^{\star \star \star}\end{array}$ & $\begin{array}{c}-0.0309 \\
(-3.018)^{\star \star *}\end{array}$ \\
\hline T88 & $\begin{array}{c}-0.0273 \\
(-2.841)^{\star \star \star}\end{array}$ & $\begin{array}{c}-0.0259 \\
(-2.703)^{\star \star \star}\end{array}$ & $\begin{array}{c}-0.0271 \\
(-2.832)^{\star \star \star}\end{array}$ & $\begin{array}{c}-0.0258 \\
(-2.698)^{\star \star \star}\end{array}$ & $\begin{array}{c}-0.0275 \\
(-2.872)^{\star \star \star}\end{array}$ \\
\hline$T 89$ & $\begin{array}{c}-0.0224 \\
(-2.315)^{\star \star}\end{array}$ & $\begin{array}{c}-0.0219 \\
(-2.257)^{\star \star \star}\end{array}$ & $\begin{array}{c}-0.0227 \\
(-2.340)^{\star *}\end{array}$ & $\begin{array}{c}-0.0218 \\
(-2.244)^{\star \star \star}\end{array}$ & $\begin{array}{c}-0.0246 \\
(-2.532)^{\star \star}\end{array}$ \\
\hline T90 & $\begin{array}{l}-0.0050 \\
(-0.557)\end{array}$ & $\begin{array}{l}-0.0056 \\
(-0.618)\end{array}$ & $\begin{array}{l}-0.0054 \\
(-0.596)\end{array}$ & $\begin{array}{l}-0.0055 \\
(-0.610)\end{array}$ & $\begin{array}{l}-0.0072 \\
(-0.793)\end{array}$ \\
\hline T91 & $\begin{array}{l}0.0157 \\
(1.600)\end{array}$ & $\begin{array}{l}0.0142 \\
(1.452)\end{array}$ & $\begin{array}{l}0.0148 \\
(1.509)\end{array}$ & $\begin{array}{l}0.0143 \\
(1.464)\end{array}$ & $\begin{array}{l}0.0105 \\
(1.083)\end{array}$ \\
\hline$N$ & 1,010 & 1,010 & 1,010 & 1,010 & 1,010 \\
\hline$R^{2}$ & 0.8353 & 0.8358 & 0.8354 & 0.8358 & 0.8402 \\
\hline SSR & 5.2253 & 5.2081 & 5.2220 & 5.2079 & 5.0677 \\
\hline$F$ & $13.01^{\star \star \star}$ & $12.99 \star \star \star$ & $12.95^{\star \star \star}$ & $12.93^{\star \star \star}$ & $13.04^{\star \star \star}$ \\
\hline
\end{tabular}

Significance levels: $*$ at 0.10 ; $* *$ at $0.05 ; * * *$ at 0.01 . Asymptotic t-values in parentheses. 
Table 6. Panel estimations using different functional form

\begin{tabular}{|c|c|c|c|c|}
\hline \multirow[b]{2}{*}{ Variable } & \multicolumn{2}{|c|}{ Linear functional form } & \multicolumn{2}{|c|}{ Logistic functional form } \\
\hline & $\begin{array}{c}\text { Coefficient } \\
(t=b / s . e .)\end{array}$ & $\begin{array}{c}\text { Coefficient } \\
(t=b / s . e .)\end{array}$ & $\begin{array}{c}\text { Coefficient } \\
(t=b / \text { s.e. })\end{array}$ & $\begin{array}{c}\text { Coefficient } \\
(t=b / s . e .)\end{array}$ \\
\hline SPECIFla & $\begin{array}{c}-0.2034 \\
(-1.688)^{\star}\end{array}$ & - & $\begin{array}{l}-11.2740 \\
(-2.547)^{\star *}\end{array}$ & - \\
\hline SPECIFIb & - & $\begin{array}{c}-8.1662 \\
(-1.668)^{*}\end{array}$ & - & $\begin{array}{l}-365.7800 \\
(-1.966)^{\star *}\end{array}$ \\
\hline UNCERTA & $\begin{array}{c}-0.0561 \\
(-1.900)^{\star}\end{array}$ & $\begin{array}{c}-0.0721 \\
(-2.209)^{\star *}\end{array}$ & $\begin{array}{l}0.9118 \\
(0.827)\end{array}$ & $\begin{array}{l}0.2693 \\
(0.250)\end{array}$ \\
\hline UNCE*SPECla & $\begin{array}{l}0.0505 \\
(0.165)\end{array}$ & - & $\begin{array}{l}-6.9583 \\
(-0.419)\end{array}$ & - \\
\hline UNCE*SPECIb & - & $\begin{array}{c}14.3690 \\
(1.023)\end{array}$ & - & $\begin{array}{c}356.0400 \\
(0.678)\end{array}$ \\
\hline PRDVAR & $\begin{array}{c}0.0203 \\
(2.280)^{\star *}\end{array}$ & $\begin{array}{c}0.0205 \\
(2.327)^{\star \star}\end{array}$ & $\begin{array}{c}0.9526 \\
(2.126)^{\star \star}\end{array}$ & $\begin{array}{c}0.9739 \\
(2.183)^{\star \star}\end{array}$ \\
\hline PRDVAR2 & $\begin{array}{c}-0.0016 \\
(-2.026)^{\star \star}\end{array}$ & $\begin{array}{c}-0.0016 \\
(-2.072)^{\star \star}\end{array}$ & $\begin{array}{c}-0.0605 \\
(-1.717)^{\star}\end{array}$ & $\begin{array}{c}-0.0617 \\
(-1.772)^{*}\end{array}$ \\
\hline GEODIS & $\begin{array}{l}-0.0026 \\
(-1.020)\end{array}$ & $\begin{array}{l}-0.0023 \\
(-0.924)\end{array}$ & $\begin{array}{l}0.0821 \\
(0.900)\end{array}$ & $\begin{array}{l}0.0965 \\
(1.041)\end{array}$ \\
\hline GEODIS2 & $\begin{array}{l}0.0000 \\
(0.969)\end{array}$ & $\begin{array}{l}0.0000 \\
(0.871)\end{array}$ & $\begin{array}{l}-0.0015 \\
(-0.933)\end{array}$ & $\begin{array}{l}-0.0017 \\
(-1.082)\end{array}$ \\
\hline INTANG & $\begin{array}{c}1.6045 \\
(3.570)^{\star \star \star}\end{array}$ & $\begin{array}{c}1.6223 \\
(3.653)^{\star \star \star}\end{array}$ & $\begin{array}{l}44.8460 \\
(1.710)^{*}\end{array}$ & $\begin{array}{l}45.6960 \\
(1.765)^{\star}\end{array}$ \\
\hline T87 & $\begin{array}{c}-0.0309 \\
(-3.018)^{\star \star \star}\end{array}$ & $\begin{array}{c}-0.0311 \\
(-2.992)^{\star \star \star}\end{array}$ & $\begin{array}{c}-1.8379 \\
(-3.455)^{\star \star \star}\end{array}$ & $\begin{array}{c}-1.8667 \\
(-3.423)^{\star \star \star}\end{array}$ \\
\hline T88 & $\begin{array}{c}-0.0275 \\
(-2.872)^{\star \star \star}\end{array}$ & $\begin{array}{c}-0.0249 \\
(-2.643)^{\star \star \star}\end{array}$ & $\begin{array}{c}-1.4446 \\
(-3.069)^{\star \star \star}\end{array}$ & $\begin{array}{c}-1.2920 \\
(-2.838)^{\star \star \star}\end{array}$ \\
\hline T89 & $\begin{array}{c}-0.0246 \\
(-2.532)^{\star \star}\end{array}$ & $\begin{array}{c}-0.0198 \\
(-2.138)^{\star \star}\end{array}$ & $\begin{array}{c}-1.5234 \\
(-3.352)^{\star \star \star}\end{array}$ & $\begin{array}{c}-1.2433 \\
(-2.902)^{\star \star \star}\end{array}$ \\
\hline T90 & $\begin{array}{l}-0.0072 \\
(-0.793)\end{array}$ & $\begin{array}{l}-0.0029 \\
(-0.308)\end{array}$ & $\begin{array}{l}-0.6543 \\
(-1.507)\end{array}$ & $\begin{array}{l}-0.4430 \\
(-1.023)\end{array}$ \\
\hline T91 & $\begin{array}{l}0.0105 \\
(1.083)\end{array}$ & $\begin{array}{l}0.0106 \\
(1.088)\end{array}$ & $\begin{array}{l}-0.0961 \\
(-0.212)\end{array}$ & $\begin{array}{l}-0.0974 \\
(-0.215)\end{array}$ \\
\hline$N$ & 1,010 & 1,010 & 1,010 & 1,010 \\
\hline$R^{2}$ & 0.8402 & 0.8403 & 0.8192 & 0.8190 \\
\hline SSR & 5.0677 & 5.0645 & 11,547 & 11,560 \\
\hline$F$ & $13.04^{\star \star \star}$ & $13.05^{\star \star \star}$ & $11.23^{\star \star *}$ & $11.22^{\star \star \star}$ \\
\hline
\end{tabular}

